\title{
先天異常に起因する顎変形症の治療 \\ Treatment for jaw deformity due to congenital anomalies
}

\author{
飯田順一郎 \\ Junichiro Iida \\ 北海道大学大学院歯学研究科 口䏶機能学講座 \\ 歯科矯正学教室 \\ Department of Orthodontics, Graduate School of Dental Medicine, Hokkaido University \\ 古郷 幹彦
Mikihiko Kogo \\ 大阪大学大学院歯学研究科 顎口腔病因病態制御学講座 \\ 口腔外科学第一教室 \\ $1^{\text {st }}$ Dept. of Oral and Maxillofacial Surgery, Osaka University Graduate School of Dentistry
}

先天異常に起因して顎顔面形態に異常を有する患者として, 臨床上最も多く遭遇するのが唇顎口蓋 裂を有する患者である。唇顎口蓋裂の患者に対する口蓋閉鎖術等の手術的アプローチの進歩により， 劣成長とされる顎骨の成長発育は大きく改善されてきている。しかし外科的矯正治療が必要となる患 者は依然多い。また，唇顎口蓋裂に留まらず，頭蓋顎顔面部に先天的要因で変形を生じるCrouzon 症候群, Apert 症候群, Treacher Collins 症候群等々, 現時点で 41 の疾患に対して, 矯正歯科治療 に保険が適応されている。これらの患者の治療において, 顎骨の位置, 形態の異常が著しい場合はそ れを改善するために, 外科的処置が必要になる場合が多い。またこのような患者においては, 不正咬 合の改善を目的とするだけでなく, 患者が社会生活を支障なく営み, また精神的な安寧を得るために も, 変形している頭蓋顎顔面骨格形態の改善を目的として外科的処置を行う場合もある。このような 先天異常に起因する頭蓋顎顔面の形態異常に対する顎変形症の治療においては, 数々の注意点, 苦労 等がそこには存在すると考えられる。

そこで本シンポジウムにおいては，このような先天異常に起因する顎変形症の治療に焦点を当て， 矯正歯科の立場から小川拓也先生 (東京医科歯科大学) に, 口腔外科の立場から須賀賢一郎先生（東 京歯科大学) と相川友直先生 (大阪大学) に, また形成外科の立場から小林眞司先生（神奈川県立こ ども医療センター）に，それぞれの専門領域の立場から，症例等を含めてご発表いただき，現状にお ける問題点, 今後の課題等について議論したいと考える。会員諸氏におかれましても積極的に議論に ご参加いただければ幸いである。 
唇顎口蓋裂患者における䫟矯正手術施行に際して考虑 すべきこと

\title{
Basic consideration of ways to perform orthognathic surgery in cleft palate patients
}

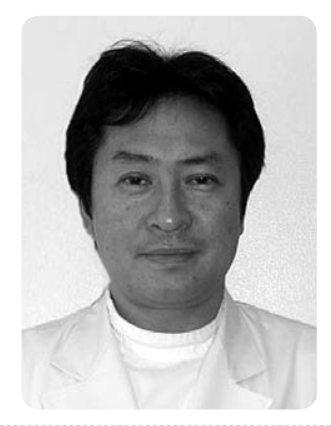

\author{
須賀賢一郎 \\ Kenichiro Suga \\ 東京歯科大学 口腔顎顔面外科学講座 \\ Department of Oral and Maxillofacial Surgery, Tokyo Dental College
}

近年，著しい顎変形をきたす口蓋裂術後患者は，少なくなってきているものの未だ皆無ではない。 口蓋裂術後患者における顎顔面変形の主因は，上顎骨の前下方および側方への成長抑制と両側裂にお ける顎間骨の発育異常である。顎顔面変形に対する外科的治療の原則は原因の存在する部位での修正 と考えるならば，口蓋裂患者の顎変形に対してはLe Fort I 型骨切り術，顎間骨に対しては顎間骨整 位術などの骨切り術が望ましい。しかし, 中にはLe Fort I 型骨切り術の適用が理論上望ましくと も, 疲痕による可動域の制限や前方移動による鼻咽腔閉鎖不全の継発などが危惧されることから，最 終的な治療方針は，two jaw surgeryによる同時移動術や骨延長術が採用されることが多い。

教室における口蓋裂術後患者に対する外科的矯正治療の方針は，1．変形を引き起こしている原因 の存在する部位で修正する。すなわち，片側裂ではLe Fort I 型骨切り術を行い，両側裂では Le Fort I 型骨切り術に加え, 顎間骨整位術を行う。2. 上下顎同時移動術での修正が容易でなければ, 骨延長術を適用する。3．顎顔面変形とくに外貌は，咬合改善にともなって自然に修正されるため, 咬合改善を主眼とした顎矯正術を行う。4. 上唇拈よび外鼻に変形をともなっている症例では, Pichler-Obwegeserの提唱する “First the bone, then the soft tissue”に則り, 骨格の改善を最初に行 う。5. 口蓋裂患者に招ける顎矯正術では, 矯正歯科医との緊密な連携のもと, 術前治療計画のみな らず，手術中における共同治療も行うなどを原則としている。

講演では, 教室で行っている顎間骨整位術, Le Fort I 型骨切り術ならびに骨延長術について症例 を供覧するとともに，手術施行に際して考慮すべき点および手術の point について解説する。 


\section{略 歴}

1989 年 7 月 東京歯科大学 口腔外科学第二講座 入局

1992 年 4 月 東京歯科大学 口腔外科学第二講座 助手

2000 年 9 月 歯学博士学位取得

2002 年 4 月 東京歯科大学 口腔外科学講座 講師

2006 年 7 月 カナダ・ダルハウジー大学 口腔外科学講座留学

現在に至る

\section{資 格}

日本口腔外科学会専門医・指導医 


\section{症候群性頭蓋縫合早期癒合症の顎顔面変形に対する 骨延長術 \\ Distraction osteogenesis for maxillofacial deformity in syndromic craniosynostosis}

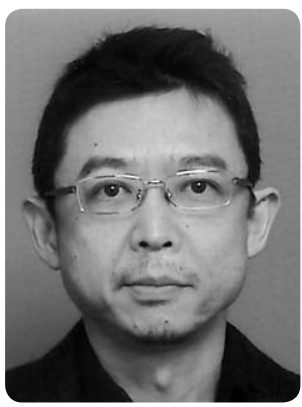

小林 眞司 ${ }^{1)}$

Shinji Kobayashi

1）神奈川県立こども医療センター 形成外科 Department of Plastic and Reconstructive Surgery, Kanagawa Children's Medical Center

府川 俊彦 ${ }^{2)}$, 平川 崇 ${ }^{3)}$, 前川 二郎 ${ }^{4)}$ Toshihiko Fukawa ${ }^{2)}$, Takashi Hirakawa ${ }^{3)}$, Jiro Maekawa ${ }^{4)}$

2) ふかわ矯正歯科

3) ひらかわ矯正歯科

4) 横浜市立大学附属病院 形成外科

2) Fukawa Orthodontic Clinic

3) Hirakawa Orthodontic Clinic

4) Department of Plastic and Reconstructive Surgery, Yokohama City University Hospital

顎顔面変形の中でも症候群性頭蓋縫合早期癒合症（SCS）に対する治療は難しい疾患の1つである。 骨延長術の進歩とともにより安全に手術が行えるようになり低年齢で施行することも多くなったが，中 顔面は低形成で，かつ成長はごくわずかであるために，成人に至るまでに複数回の手術を必要とする。

小児期での手術適応は主に呼吸障害の改善と視機能の温存であるが，成人と同等な顔貌にすること が困難であるために，再び中顔面の骨延長術が行われることが一般的である。そして，最終手術とし て顔貌と咬合の改善目的に上下顎あるいは下顎骨切り術が行われることが多い。このように, 複数回 の手術は患児の負担となっており，なるべく少ない回数の手術が望ましい。そのためには小児期でな るべく成人に近い顔貌にする必要があるが，小览では成長 Jを予測した治療目標の設定が難しいだけ でなく，実際の手術においても大幅な延長やそれに伴う方向の制御が困難であるなどの問題がある。

われわれは，これらの問題点を解決するために，まずSCS の経年的セファログラムを参考にして 独自の治療目標の設定法を考案した。さらに，その治療目標を達成するために新しく開発した創内型 三次元骨延長器と従来の創外型骨延長器により構成される「ハイブリッド型骨延長システム」を開発 した。このシステムは, 創内型延長器で中顔面骨を後方から押すことにより移動量の大きな延長にも 対応可能であり，創外型延長器に取り付けられた計 6-8 本の牽引用ワイヤーで方向の制御を行う。主 な利点は，小児期での移動量の大きな延長だけでなく手術を繰り返した痏痕が強い症例に対しても延 長が可能なことや創内型延長器の取り付け時の非対称性や延長時の中顔面偏位に対しても, 延長方向 の制御が可能であることなどである。 


\section{略 歴}

1991 年 3 月 山形大学医学部 卒業

1991 年 6 月 横浜市立大学医学部附属病院 研修医

1993 年 4 月 横浜市立大学医学部附属病院 形成外科

1997 年 4 月 神奈川県立こども医療センター 形成外科 医員 2000 年 10 月 同

科長

2005 年 12 月 ハーバード大学マサチューセッツ総合病院 形成外科 リサーチフェロー

2007 年 4 月 横浜市立大学 形成外科 助教

2008 年 7 月 神奈川県立こども医療センター 形成外科 科長

2010 年 4 月 神奈川県立こども医療センター 形成外科 部長

現在に至る 


\section{先天異常疾患患者を取り巻く環境からみた顎顔面矯正治療}

一長期管理症例から一

\section{Maxillofacial orthognathics for craniofacial anomaly from the aspect of patients' surrounding circumstances: long-term management cases}

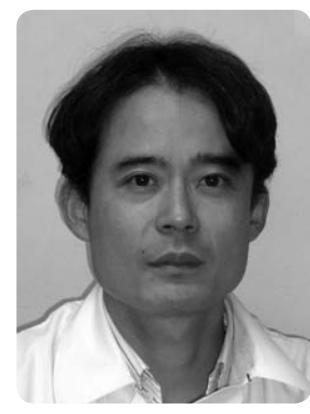

小川 卓也

Takuya Ogawa 東京医科歯科大学大学院 医歯学総合研究科 顎顔面矯正学分野 Maxillofacial Orthognathics, Graduate School, Tokyo Medical and Dental University

唇顎口蓋裂患者に対する歯科矯正治療に療養給付が認められて以来，保険適応の対象となる顎顔面 先天異常疾患が増加し，これら歯科医療分野の社会的ニーズも増加してきている。顎顔面先天異常疾 患患者において顎口腔領域の形態・機能が著しく損なわれている場合，患者本人にとって大きな社会 心理的不安となっていると考えられ，外科的矯正治療を適応することで Quality of Life (QOL) の向 上に寄与すると思われる。しかしながら，歯科治療より優先させなければならない全身症状を有して いる疾患や，年齢とともに咬合状態に変化を来すような進行性の疾患に対しては，外科的矯正治療の 適応には慎重にならざるを得ない場合があるのも現実である。

一般的な外科的矯正治療のプロトコールは，術前矯正治療を行い，下顎成長が終了した後に顎矯正 手術を適応することを原則とする。しかし，顎顔面先天異常の表現型は極めてバリエーションに富ん でおり，術前矯正治療に先立ち顎矯正手術を適応せざる得ない症例や，症例によっては患者や家族の 心理的負担の軽減を図るために，下顎の成長が終了する前に顎矯正手術を適応し，咬合のみならず顔 貌の改善を比較的早期に達成することもある。このように，先天異常疾患患者に対して，顎矯正手術 適応時期を含めた長期治療計画を立案するには，個々の患者が有する多様な症状への対応，かつ患者 を取り巻く社会心理的背景への配慮を行うことが重要であると考えられる。また, 先天異常疾患の大 部分は遺伝性疾患であるため，患者だけでなくその家族に対しても，カウンセリングを通して専門的 な立場から疾患に対する情報提供と心理的な支援を行う必要もある。

本講演では, 先天異常疾患患者に対して外科的矯正治療を適応し長期管理を行った症例を中心に, われわれが経験した問題点を抽出しながら，治療の実際を概説したい。また，QOLの向上という観 点から顎矯正手術適応時期ひいてはその必要性についても皆様と議論できれば幸いである。 


\section{略 歴}

1998 年

2002 年

2002 年 2005 年

2005 年 2008 年

2008 年 2013 年

2013 年
東京医科歯科大学歯学部 卒業

東京医科歯科大学大学院医歯学総合研究科 顎顔面矯正学分野 修了

Department of Orthodontics, Dental Branch,

University of Texas at Houston Health Science Center

東京医科歯科大学歯学部附属病院矯正歯科外来 医員

東京医科歯科大学大学院医歯学総合研究科 顎顔面矯正学分野 助教

東京医科歯科大学大学院医歯学総合研究科 顎顔面矯正学分野 講師 


\section{唇顎口蓋裂の上下顎同時移動術 ; 術式，口唇外鼻軟組織 変化, 上顎の安定性について \\ Two jaw surgery for left lip and palate; surgical pro- cedures, changes in nasolabial profile, and maxillary stability of 2 jaw surgery}

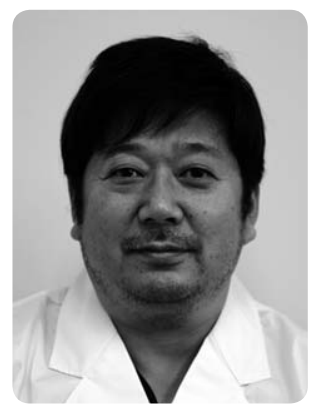

相川 友直

Tomonao Aikawa 大阪大学大学院歯学研究科 口腔外科学第一教室 $1^{\text {st }}$ Department of Oral and Maxillofacial Surgery, Osaka University Graduate School of Dentistry

口唇裂・口蓋裂手術治療と術後管理の改良により，近年では唇顎口蓋裂患者が著しい上顎劣成長や 反対咬合をきたす頻度は減少したが，それでも少なからず上顎骨の前後的，水平的，垂直的な劣成長 やカント，歯列非対称などの問題を上顎に抱えることがあり，外科的矯正治療を考慮する割合が高 い。上顎移動手術には，発音機能への影響，口唇外鼻形態への影響，口蓋から鼻腔底の骨欠損，複数 回手術後の㓔痕，など手術困難な点や言語機能など考慮すべき点も多くあるが，問題の解決には問題 の生じている部位に対する治療が適切である。実際，適切な治療計画，適切な施術がなされれば下顎 骨骨切り術単独治療や上顎骨延長術に比へ，安定した咬合獲得と審美的改善が得られる上下顎同時移 動術のアドバンテージは大きいと思われる。

上下顎同時移動術の治療に際し，特に注意を払っている点は，（1）術前言語機能評価（鼻咽腔ファ イバー検査，言語聴覚士による言語検査，側面セファロ写真（安静時，/a/ 発音時，ブローイング 時)), (2) 言語治療，矯正，口腔外科での治療計画のカンファレンスと治療説明，（3）血行維持に配 慮した治療計画，手術，（4）上顎前方移動に対する組織抵抗部位（硬口蓋－軟口蓋移行部の㓔痕，下 行口蓋動脈，翼突上顎縫合）の可動化，（5）鼻中隔軟骨の矯正，牽引と外鼻形態に対する配慮，(5) 顎裂部および骨片間への骨移植，（6）強固な骨接合，（7）術後の言語機能評価，である。

本発表では，当科で行っている唇顎口蓋裂患者に対する上下顎同時移動術のマネージメント，術 式，術後の口唇外鼻形態への影響，上顎の術後安定性について述べさせていただく予定です。 


\section{略 歴}

1990 年 3 月 広島大学歯学部 卒業

1990 年 4 月～1994 年 3 月 大阪大学大学院歯学研究科 大学院（口腔外科学第一教室）

1994 年 4 月 1997 年 3 月 日本学術振興会 特別研究員（口腔外科学第一教室）

1997 年 4 月～1998 年 2 月 大阪大学歯学部附属病院 口腔外科 1 (制御系) 医員

1998 年 2 月 1999 年 4 月 八尾徳洲会総合病院 歯科口腔外科 医長

1999 年 4 月〜 2001 年 3 月 米国マサチューセッツ総合病院 内分泌部門 研究員

2001 年 4 月～ 2003 年 3 月 大阪大学歯学部附属病院 口腔外科 1 (制御系) 医員

2003 年 3 月 2009 年 10 月 大阪大学大学院歯学研究科 口腔外科学第一教室 助教

2009 年 11 月～大阪大学歯学部附属病院 口腔外科 1 (制御系) 講師 